\title{
STUDIES ON SOME RESIDUES AND CONTAMINANTS AFFECTING THE SAFETY OF MILK AND SOME DAIRY PRODUCTS
}

\author{
Ibrahim, M. Aman' ${ }^{1}$; Azza M.K. Sobeih ${ }^{1}$ and Nahla A.A. Ebied ${ }^{2}$ \\ ${ }^{1}$ Food Control Dept., Fac. Vet. Med., Kafrelsheikh Univ., Egypt \\ ${ }^{2}$ Animal Health Research Inst., Kafr El-Sheikh Branch
}

\begin{abstract}
It is important that milk and milk products offered for sale do not contain residues at levels that exceed allowable maximum residue limits (MRLS), so this study aimed to determine the content of lead $(\mathrm{Pb})$, cadmium $(\mathrm{Cd})$, arsenic (As), copper $(\mathrm{Cu})$ and zinc $(\mathrm{Zn})$ in bulk tank milk, soft cheese, yoghurt, powdered ice cream and ice cream (30 samples each) collected from different small scale dairy plants at Kafr El-Sheikh governorate using atomic absorption spectrophotometer for analysis. The obtained results reveal that, the mean $\mathrm{Pb}$ levels in the examined bulk milk, soft cheese, yoghurt, powdered ice cream and ice cream samples were $5.5 \pm 2.7,0.2,1.28 \pm 0.55,1.32 \pm 0.6$ and 0.0 ppm, respectively. These levels were higher in bulk milk, yoghurt and powdered ice cream than the permissible limits. The mean levels of $C d$ in the same examined samples were $5.40 \pm 4.9,0.1,0.00,0.35 \pm 0.22$ and 0.00 ppm, respectively. The obtained levels of $C d$ were higher in bulk milk, soft cheese and powdered ice cream than the permissible limits. For $\mathrm{Cu}$, the mean levels were $5.39 \pm 2.02,2.58 \pm 0.24,1.28 \pm$ $0.13,2.34 \pm 0.24$ and $1.33 \pm 0.43$ ppm, respectively, while for $\mathrm{Zn}$, they were $2.70 \pm 0.19,7.26 \pm 0.67,10.22 \pm 0.44,2.34 \pm 0.24$ and $2.50 \pm 0.34 \mathrm{ppm}$ respectively in the examined samples, respectively. $\mathrm{Cu}$ and $\mathrm{Zn}$ values were higher than the permissible limits. Arsenic could not be detected from any of the examined samples. Possible health risk of these metals was discussed.
\end{abstract}

Keywords: heavy metals, milk, dairy products 


\section{INTRODUCTION}

Heavy metals represent one of the most important groups of pollutants. Toxic metals are present in the environment either naturally or as a consequence of industrial and/or agricultural activities. They find their way to milk through animal feed, water, air, during milk production, dairy processing or during packaging and storage (Kahniki, 2007).

Heavy metals such as $\mathrm{Cd}, \mathrm{Pb}$ and $\mathrm{As}$ are not expected to have any direct contact with milk and milk products, except in accidental cases. Milk products contamination reflects the level found in fresh milk, taking into account concentration factors (Hummelen, 2007). Metals may be associated with particular milk fractions e.g. $\mathrm{Pb}$ and $\mathrm{Cd}$ bind strongly to casein. The use of specific milk fraction may thus concentration or remove metals (Jansen, 1996).

Excessive intake of heavy metals $\mathrm{Pb}$ to many cases of intoxication, ranged between the gastrointestinal disturbance to liver and kidney dysfunction and lung carcinoma (Gracey and Collins, 1992). For example, $\mathrm{Pb}$ causes encephalopathy in children usually followed by permanent CNS damage (Carl, 1991). While in adults avitaminosis, loss of weight and anaemia, liver dysfunction, kidney damage, GIT irritation tumor formation and cardiovascular problems (Farag et al., 2009). Chronic $\mathrm{Pb}$ poisoning is characterized by anaemia, muscular pains, changes in arterial elasticity resulting in hypertension, toxic effects on reproductive system and $\mathrm{Pb}$ nephropathy (Goyer, 1993). 
Cadmium is an accumulative toxic metal, the main sites of deposition are liver and kidney (Cussads, 1995). Possible sources of environmental pollution are through galvanized pipes, pigments, rechargeable batteries, plastics, and effluents from electroplating works, however, food is the primary source of exposure (WHO, 1995 and Dwivedi et al., 1997). Anaemia is a common manifestation of chronic $\mathrm{Cd}$ toxicity due to its antagonism to $\mathrm{Cu}$ and iron $($ IARC, 1994).

Arsenic occurs naturally in the environment as an element of the earth's crust and combined with elements such as oxygen, chlorine and sulfur to form inorganic arsenic compounds. Chronic exposure to arsenic can $\mathrm{Pb}$ to dermatitis hyperkeratinization of exposed areas and lung cancer, while acute exposure can cause lung distress and death (Osha, 2008).

Copper is an essential element for all plants and animals. It is widely distributed and occurred in food in many chemical forms which affects its availability to the animals (Watson, 1993). Both deficiency and excess of $\mathrm{Cu}$ in the mammalian system results in untowards effects (Hostynek et al., 1993). High $\mathrm{Cu}$ levels $\mathrm{Pb}$ to various diseases include Mediterranean anaemia., cirrhosis, yellow atrophy of liver and Wilson's disease (hepatolenticular degeneration) (Underwood, 1977 and Goyer, 1996).

Zinc is essential for biological function as protein synthesis and carbohydrate metabolism. A number of diseases and dermatological conditions are attributed to $\mathrm{Zn}$ deficiency, such as alopecia, acrodermatitis, and enteropthica (Miyata et al., 1986). On the contrary high levels of dietary $\mathrm{Zn}$ may interfere with the hepatic $\mathrm{Cu}$ storage and 
may compete with calcium for intestinal absorption. The antagonistic effects of $\mathrm{Zn}$ against iron and $\mathrm{Cu}$ can result in suppression of hematopoiesis (Osweiler, 1996). Therefore, this study was conducted to throw light on the level of some heavy metals ( $\mathrm{Pb}, \mathrm{Cd}, \mathrm{As}, \mathrm{Cu}$ and $\mathrm{Zn}$ ) in milk and some dairy products (soft cheese, yoghurt, powdered ice cream and ice cream) and compare the level of these metallic elements in the examined samples with MPL.

\section{MATERIALS AND METHODS}

\section{Collection of samples:}

One hundred and fifty random samples of bulk milk and some dairy products including soft-cheese, yoghurt, powdered ice cream and ice cream (30 samples of each) were collected from small scale dairy plants in Kafr El-Sheikh governorate during 2010 and 2011. Samples were transferred to the laboratory in ice-pack containers where kept frozen until analysis.

\section{Preparation:}

Each sample was prepared according to APHA (1992), then was digested by wet way according to Tsoumbaris and Papadopulou (1994) using 5 grams from each sample.

\section{Analytical procedures:}

All samples were analyzed using air-acetylene unit in atomic absorption spectrophotometer GBC (Avanta) at Central Laboratory of Kafrelsheikh University for determination of $\mathrm{Pb}, \mathrm{Cd}, \mathrm{As}, \mathrm{Cu}$ and $\mathrm{Zn}$. The accuracy of the method was confirmed by analysis of standard reference 
Studies On Some Residues And Contaminants Affecting ...

material calibration against standard solutions (Mono-element CPA chem.., Bulgaria) for all elements. Calibration graphs were linear in the ranges of 5$150 \mathrm{ppm}$ for As, 1-5 ppm for $\mathrm{Pb}$ and $\mathrm{Cu}$ and 0.5-1.5 ppm for $\mathrm{Zn}$ and $\mathrm{Cd}$. Blank absorbance values were monitored throughout the experiment and were subtracted from the readings before the results were calculated.

\section{Statistical analysis:}

Data groups for each element were statistically analyzed according to Petrie and Watson (1999).

\section{RESULTS}

Table (1): Lead contents in the examined milk and dairy products samples and percent above maximum permissible limits (M.P.L.).

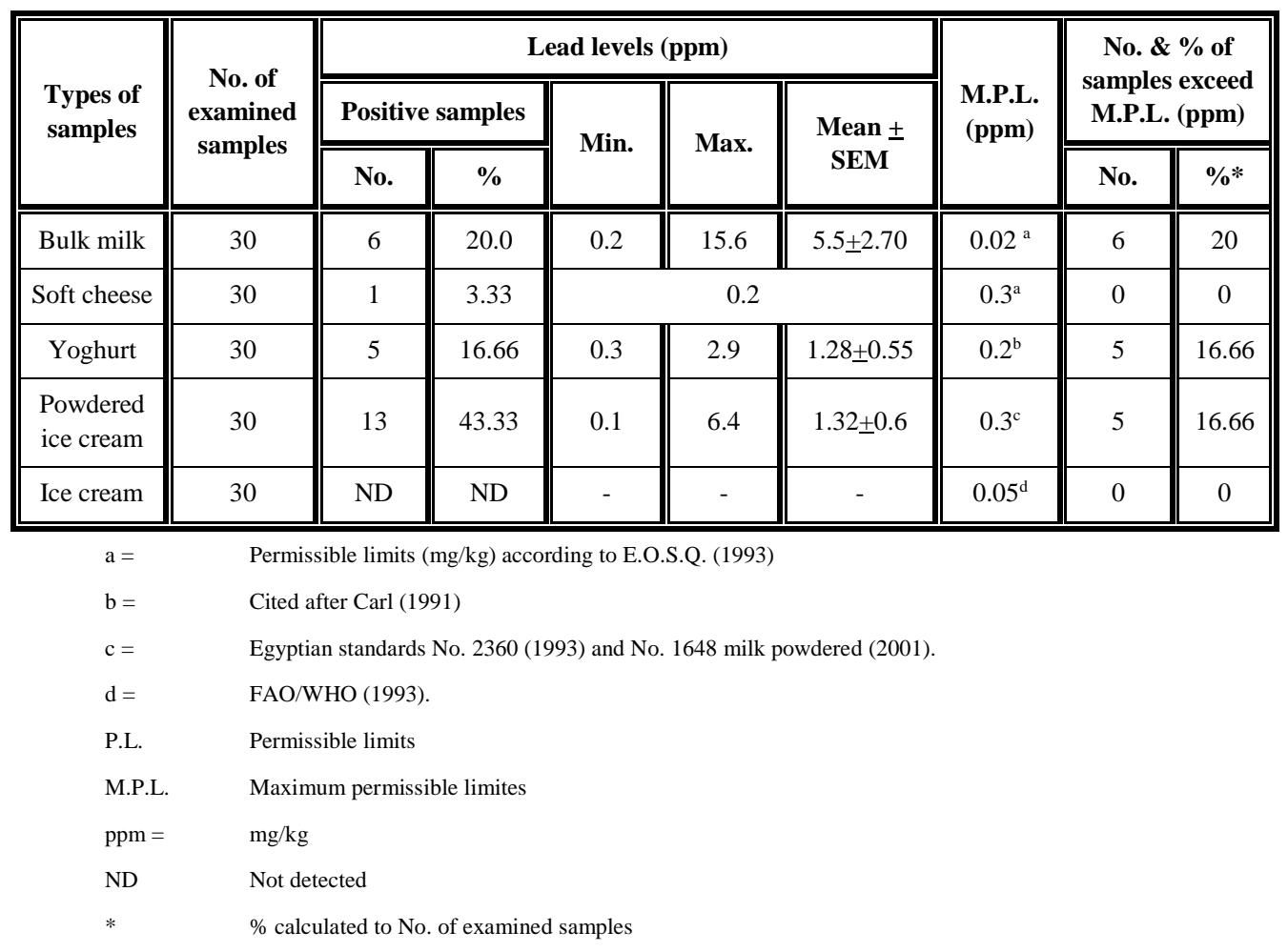

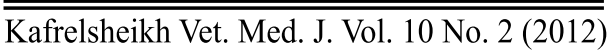


Ibrahim, M. Aman et., al.

Table (2): Cadmium and arsenic contents in the examined milk and dairy products samples and percent above maximum permissible limits (M.P.L.).

\begin{tabular}{|c|c|c|c|c|c|c|c|c|c|c|}
\hline \multirow{3}{*}{$\begin{array}{l}\text { Types of } \\
\text { samples }\end{array}$} & \multirow{3}{*}{$\begin{array}{c}\text { No. of } \\
\text { examined } \\
\text { samples }\end{array}$} & \multicolumn{5}{|c|}{ Cadmium levels (ppm) } & \multirow{3}{*}{$\begin{array}{l}\text { M.P.L. } \\
\text { (ppm) }\end{array}$} & \multirow{2}{*}{\multicolumn{2}{|c|}{$\begin{array}{c}\text { No. \& \% of } \\
\text { samples exceed } \\
\text { P.L. (ppm) }\end{array}$}} & \multirow{3}{*}{$\begin{array}{c}\text { Arsenic } \\
\text { level } \\
\text { (ppm }\end{array}$} \\
\hline & & \multicolumn{2}{|c|}{ Positive samples } & \multirow{2}{*}{ Min. } & \multirow{2}{*}{ Max. } & \multirow{2}{*}{$\underset{\text { SEM }}{\operatorname{Mean} \pm}$} & & & & \\
\hline & & No. & $\%$ & & & & & No. & $\% *$ & \\
\hline Bulk milk & 30 & 2 & 6.66 & 0.5 & 10.3 & $\begin{array}{c}5.4 \pm \\
4.9\end{array}$ & $0.05^{\mathrm{a}}$ & 2 & 6.66 & ND \\
\hline Soft cheese & 30 & 1 & 3.33 & 0.1 & 0.1 & 0.1 & $0.05^{\mathrm{a}}$ & 1 & 3.33 & ND \\
\hline Yoghurt & 30 & $\mathrm{ND}$ & ND & - & - & - & $0.03^{\mathrm{e}}$ & ND & $\mathrm{ND}$ & ND \\
\hline $\begin{array}{l}\text { Powdered } \\
\text { ice cream }\end{array}$ & 30 & 4 & 13.33 & 0.1 & 1 & $\begin{array}{c}0.35 \pm \\
0.22\end{array}$ & $0.05^{\mathrm{f}}$ & 4 & 13.33 & ND \\
\hline Ice cream & 30 & $\mathrm{ND}$ & ND & - & - & - & $0.05^{\mathrm{d}}$ & ND & ND & ND \\
\hline $\mathrm{a}=$ & $\overline{\text { Pern }}$ & ble lim & $\mathrm{mg} / \mathrm{kg})$ & accordi & g to E. & ).S.Q. (19 & & & & \\
\hline $\mathrm{d}=$ & $\mathrm{FAO} /$ & $\mathrm{HO}(1 \mathrm{~s}$ & & & & & & & & \\
\hline $\mathrm{e}=$ & Europ & an maxi & $n$ level & & & & & & & \\
\hline$f=$ & Citek & tal. $(19$ & & & & & & & & \\
\hline P.L. & Permi & sible lim & & & & & & & & \\
\hline M.P.L & Maxin & um pern & ble $\lim$ & & & & & & & \\
\hline $\mathrm{ppm}=$ & $\mathrm{mg} / \mathrm{k}$ & & & & & & & & & \\
\hline ND & Not d & ected & & & & & & & & \\
\hline$*$ & $\% \mathrm{cal}$ & lated to & of exa & nined & mples & & & & & \\
\hline
\end{tabular}

Table (3): Copper contents in the examined milk and dairy products samples and percent above maximum permissible limits (M.P.L.).

\begin{tabular}{|c|c|c|c|c|c|c|c|c|c|}
\hline \multirow{3}{*}{$\begin{array}{l}\text { Types of } \\
\text { samples }\end{array}$} & \multirow{3}{*}{$\begin{array}{c}\text { No. of } \\
\text { examined } \\
\text { samples }\end{array}$} & \multicolumn{5}{|c|}{ Copper levels (ppm) } & \multirow{3}{*}{$\begin{array}{c}\text { M.P.L. } \\
\text { (ppm) }\end{array}$} & \multirow{2}{*}{\multicolumn{2}{|c|}{$\begin{array}{c}\text { No. \& \% of } \\
\text { samples exceed } \\
\text { P.L. (ppm) }\end{array}$}} \\
\hline & & \multicolumn{2}{|c|}{ Positive samples } & \multirow{2}{*}{ Min. } & \multirow{2}{*}{ Max. } & \multirow{2}{*}{$\underset{\text { SEM }}{\operatorname{Mean} \pm}$} & & & \\
\hline & & No. & $\%$ & & & & & No. & $\% *$ \\
\hline Bulk milk & 30 & 30 & 100 & 0.8 & 52.8 & $5.39 \pm 2.02$ & $0.10^{\mathrm{h}}$ & 30 & 100 \\
\hline Soft cheese & 30 & 30 & 100 & 1.1 & 7.5 & $2.58+0.24$ & $0.3^{\mathrm{a}}$ & 30 & 100 \\
\hline Yoghurt & 30 & 29 & 96.66 & 0.1 & 2.4 & $1.28 \pm 0.13$ & $0.4^{\mathrm{f}}$ & 24 & 80 \\
\hline $\begin{array}{l}\text { Powdered } \\
\text { ice cream }\end{array}$ & 30 & 30 & 100 & 1.4 & 6.6 & $2.34 \pm 0.24$ & $3.0^{\mathrm{a}}$ & 5 & 16.66 \\
\hline Ice cream & 30 & 30 & 100 & 0.2 & 13.5 & $1.33+0.43$ & $0.4^{\mathrm{f}}$ & 27 & 90.00 \\
\hline
\end{tabular}

$\begin{array}{ll}\mathrm{h}= & \text { IDF 1979. International Dairy Federation. } \\ \mathrm{a}= & \text { Permissible limits (mg/kg) according to E. } \\ \mathrm{f}= & \text { Citek } \text { et al. } \text { (1996) } \\ \mathrm{P} . \mathrm{L} . & \text { Permissible limits } \\ \text { M.P.L. } & \text { Maximum permissible limits } \\ \mathrm{ppm}= & \mathrm{mg} / \mathrm{kg} \\ \mathrm{ND} & \text { Not detected } \\ * & \% \text { calculated to No. of examined samples }\end{array}$

$\overline{\text { Kafrelsheikh Vet. Med. J. Vol. } 10 \text { No. } 2 \text { (2012) }}$ 
Studies On Some Residues And Contaminants Affecting ...

Table (4): Zinc contents in the examined milk and dairy products samples and percent above maximum permissible limits (M.P.L.).

\begin{tabular}{|c|c|c|c|c|c|c|c|c|c|}
\hline \multirow{3}{*}{$\begin{array}{l}\text { Types of } \\
\text { samples }\end{array}$} & \multirow{3}{*}{$\begin{array}{c}\text { No. of } \\
\text { examined } \\
\text { samples }\end{array}$} & \multicolumn{5}{|c|}{ Zinc levels (ppm) } & \multirow{3}{*}{$\begin{array}{c}\text { M.P.L. } \\
\text { (ppm) }\end{array}$} & \multirow{2}{*}{\multicolumn{2}{|c|}{$\begin{array}{c}\text { No. \& \% of } \\
\text { samples exceed } \\
\text { P.L. (ppm) }\end{array}$}} \\
\hline & & \multicolumn{2}{|c|}{ Positive samples } & \multirow{2}{*}{ Min. } & \multirow{2}{*}{ Max. } & \multirow{2}{*}{ Mean \pm SEM } & & & \\
\hline & & No. & $\%$ & & & & & No. & $\% *$ \\
\hline Bulk milk & 30 & 30 & 100 & 1 & 4.9 & $2.7 \pm 0.19$ & $3.28^{\mathrm{h}}$ & 9 & 30 \\
\hline Soft cheese & 30 & 30 & 100 & 0.8 & 14.1 & $7.26 \pm 0.67$ & $12.0^{\mathrm{g}}$ & 2 & 6.66 \\
\hline Yoghurt & 30 & 30 & 100 & 4.4 & 15.1 & $10.22 \pm 0.44$ & $5.0^{\mathrm{a}}$ & 28 & 93.33 \\
\hline $\begin{array}{l}\text { Powdered } \\
\text { ice cream }\end{array}$ & 30 & 30 & 100 & 0.2 & 26.4 & $7.48 \pm 1.11$ & $15.0^{\mathrm{a}}$ & 2 & 6.66 \\
\hline Ice cream & 30 & 30 & 100 & 0.8 & 7.7 & $2.5 \pm 0.34$ & $5.0^{\mathrm{a}}$ & 3 & 10 \\
\hline
\end{tabular}

$\begin{array}{ll}\mathrm{a}= & \text { Permissible limits }(\mathrm{mg} / \mathrm{kg}) \text { according to E.O.S.Q. (1993) } \\ \mathrm{g}= & \text { Csapo (2002) } \\ \mathrm{h}= & \text { IDF 1979. International Dairy Federation. Bulletin, Chemical residues in milk and milk products. } \\ \text { P.L. } & \text { Permissible limits } \\ \text { M.P.L. } & \text { Maximum permissible limits } \\ \text { ppm }= & \mathrm{mg} / \mathrm{kg} \\ \text { ND } & \text { Not detected } \\ * & \% \text { calculated to No. of examined samples }\end{array}$

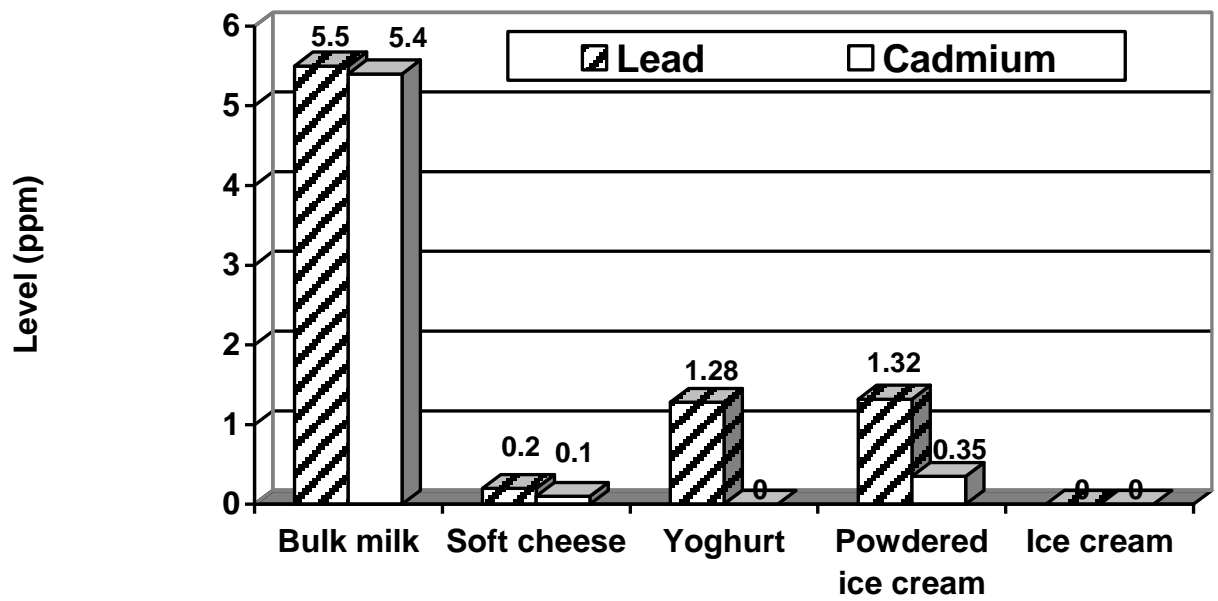

Type of samples

Fig. (1): Mean values of lead and cadmium (ppm) in the milk and dairy products samples.

$\overline{\text { Kafrelsheikh Vet. Med. J. Vol. } 10 \text { No. } 2 \text { (2012) }}$ 


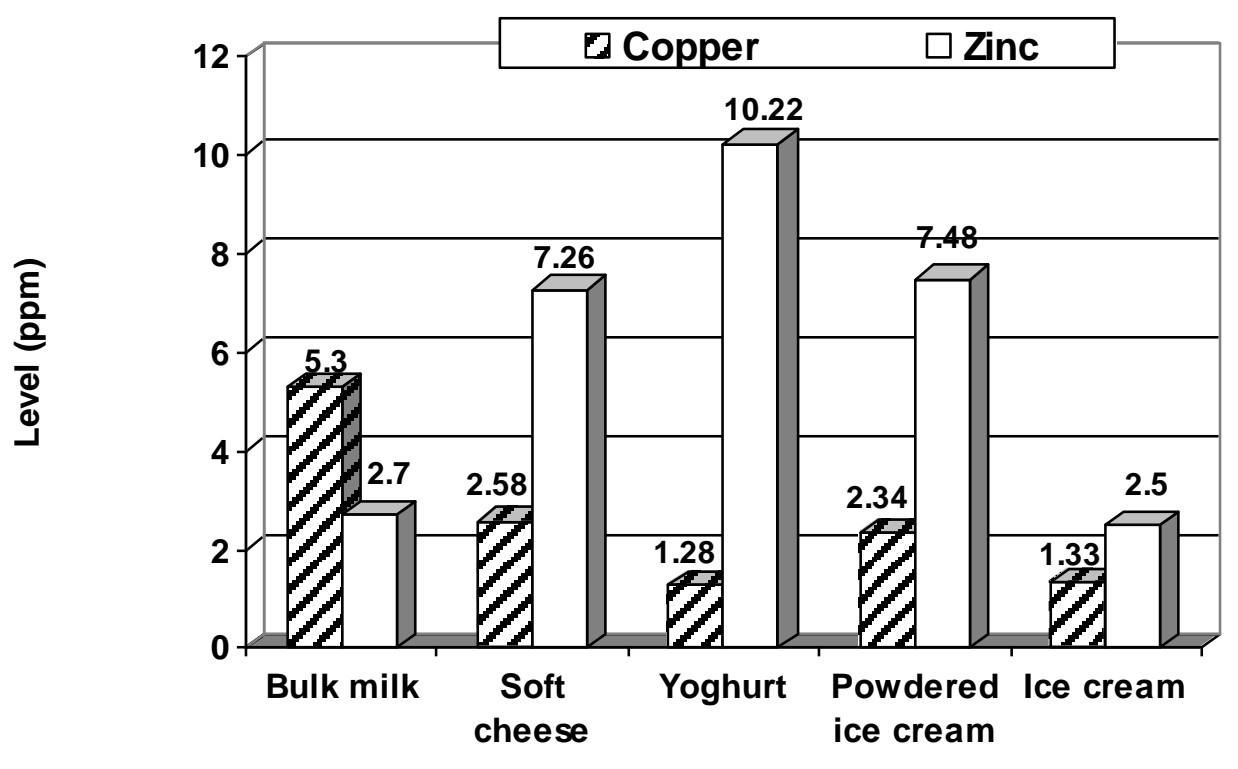

Type of samples

Fig. (2): Mean values of copper and zinc (ppm) in the milk and dairy products samples.

\section{DISCUSSION}

Contamination of food and milk by heavy metals is one of the major problems affecting human health. The main source of these heavy metals is the overuse of fertilizers and increase industrial activity. Industrial and agricultural use of heavy metals and their compounds resulted in environmental pollution and presence of metal residues in food chain (Tork, 1996).

Results recorded in (Table 1 and Fig. 1) reveal that $\mathrm{Pb}$ was detected in the examined samples of bulk milk (20\%), soft cheese $(3.33 \%)$, yoghurt, (16.66\%) and powdered ice cream (43.33\%) with mean values \pm SEM of $5.5 \pm 2.7,0.2,1.28 \pm 0.55$ and $1.32 \pm 0.6$, respectively, but not detected in ice cream samples. 
In comparison with the permissible limits of $\mathrm{Pb}$ in bulk milk $(0.02$ $\mathrm{ppm})$ and powered ice cream $(0.3 \mathrm{ppm})$ according to Egyptian standard 6 (20\%) and $5(16.66 \%)$ of the examined samples exceed the MRL, while the only one positive sample of cheese is lower than the MPL (0.3 ppm). Regarding yoghurt, the five positive (16.66\%) samples exceed the MRL of $\mathrm{Pb}(0.2 \mathrm{ppm})$ as reported by (Carl, 1991) (Table 1). Consequently, bulk milk, yoghurt and powered ice cream represent high risk of consumer.

The given results in (Table 2 and Fig. 2) reveal that $\mathrm{Cd}$ was detected in $2(6.66 \%), 1(3.33 \%)$ and $4(13.33 \%)$ out of the examined bulk milk, soft cheese and powdered ice cream samples with mean values \pm SEM of $5.4 \pm 4.9,0.1$ and $0.35 \pm 0.22$ respectively, but not detected in yoghurt and ice cream samples.

The obtained results were higher than those recorded by El-Prince and Sharkawy (1999), Pavlovic et al. (2004) and Maas et al. (2011). According to Egyptian standard, the positive samples of bulk milk (2) and soft cheese (one exceeded the MPL of Cd (0.05 ppm), also the four positive samples of powdered ice cream exceeded the same limit that mentioned by Citek et al. (1995). Presence of $\mathrm{Cd}$ in bulk milk may be attributed to grazing of dairy animals near high ways or animal held in industrial areas, as $\mathrm{Cd}$ widely used in industry and has the ability to spread through environment (Venalainen et al., 1996 and Daganoc, 1999). Also, Cd contaminates the food chain via the use of the sewage sludge and the phosphate compounds as land's fertilizers that results in increased Cd level in animal's feed and milk (Robards and Worsfold, 1991 and Morcombe et al., 1994). 
Exposure to arsenic is mainly via food intake and drinking water. Long term exposure to As is related to risk of various forms of cancer (mainly skin cancer) and numerous non-cancer diseases including skin lesions, diabetes, chronic cough and toxic effect on liver, kidney, cardiovascular system and peripheral and central nervous system (Jarup, 2003, Vahter, 2007 and Sobeih and Hegazy, 2011). Arsenic could not be detected from any of the examined bulk milk and dairy products samples (Table 2).

The mean levels of $\mathrm{Cu}$ in the examined bulk milk, soft cheese, yoghurt, powder ice cream and ice cream samples were detected as follows $5.39 \pm 2.02,2.58 \pm 0.24,1.28 \pm 1.13,2.34 \pm 0.24$ and $1.33 \pm 0.43$ ppm, respectively. Higher results were reported by Deeb (2010) and Adetunji and Salawu (2008) while lower levels were reported by Citek et al. (1995) and Nasr et al. (2007). (Table 3 and Fig. 2)

Egyptian standard (E.O.S.Q., 1993) cited MPL for $\mathrm{Cu}$ as $0.3 \mathrm{ppm}$ in soft cheese and $3.0 \mathrm{ppm}$ in powdered ice cream. Accordingly, 30 (100\%) and $5(16.66 \%)$ of the examined samples exceed these limits (Table 3$)$. Moreover, all bulk milk samples exceed the MPL of $\mathrm{Cu} 0.1 \mathrm{ppm}$ cited by IDF (1979). Comparing our results with the PML (0.4 ppm) of $\mathrm{Cu}$ reported by Citek et al. (1995), 24 (80\%) and 27 (90\%) of yoghurt and ice cream samples exceeded this limit (Table 3).

Although $\mathrm{Cu}$ is an essential trace element (at low concentration), it is toxic at high level. Daily intake of an excessive dose of $\mathrm{Cu}$ may $\mathrm{Pb}$ to Wilson's disease which is manifested by destruction of nerve cells, liver cirrhosis, ascitis, oedema and hepatic failure (Gossel and Bricker, 1990). Moreover, high level of $\mathrm{Cu}$ in milk has an adverse effect on lactic acid bacteria and production of dairy products with bad quality (Bottazzi et al., 2000). 
The mean levels of $\mathrm{Zn}$ in the examined bulk milk, soft cheese, yoghurt, powdered ice cream and ice cream samples were recorded as follows $2.70 \pm 0.19,7.26 \pm 0.67,10.22 \pm 0.44,7.48 \pm 1.11$ and $2.50 \pm$ 0.34 ppm, respectively lower values were reported by Moreno Rojas et al. (2000), El-Prince and Abdel-Mohsen (2001) and Jeena Zagroska (2007). Nearly similar results were obtained by Ukic (1998); and higher results which exceeded the MRLs were recorded by Miedzobrodzka et al. (1995). (Table 4 and Fig. 2)

Egyptian Standard, (E.O.S.Q.C., 1993) cited MPL for $\mathrm{Zn}$ as 5.0 ppm in yoghurt, $15 \mathrm{ppm}$ in powdered ice cream and $5.0 \mathrm{ppm}$ in ice cream. Accordingly, $28(93.33 \%), 2(6.66 \%)$ and $3(10 \%)$ of the examined samples exceed these limits (Table 4). While in bulk milk samples 9 (30\%) exceed the MPL of Zn (3.28) cited by IDF (1979). Moreover, 2 (6.66\%) soft cheese samples exceeded the MPL of Zn 12.0 ppm cited by (Csapo and Csapone, 2002) (Table 4).

High level of dietary $\mathrm{Zn}$ may interfere with the hepatic $\mathrm{Cu}$ storage and may compete with calcium for intestinal absorption. The antagonistic effects of $\mathrm{Zn}$ against iron and $\mathrm{Cu}$ can result in suppression of hematopoiesis (Osweiler, 1996)

In conclusion, high concentrations of $\mathrm{Pb}$ and $\mathrm{Cd}$ were detected in bulk milk and dairy products. It is necessary to warning about the hazardous effects of these toxic elements on human being. The consuming of such products considered as an additional source of exposure beside the direct sources of air, water and plants. Moreover, the effect of consumers may contribute through disturbing the levels of essential elements $(\mathrm{Cu}$ and $\mathrm{Zn})$ in vital foods. 
Therefore, the preventive measures for minimizing the pollution of milk and milk products with such metals are of significant concern and regular examination of milk and dairy products and their load for heavy metals should be evaluated according to the international guidelines.

\section{REFERENCES}

- Adetunji, V.O. and Salawu, O.T. (2008). West African soft cheese 'wara' prcessed with Calotropis procera and Carica papaya: a comparative assessment of nutritional values. African Journal of Biotechnology, 7(18): 3360-3362.

- APHA (American Public Health Association) (1992). Standard method for examination of dairy products. $16^{\text {th }}$ ed. New York, USA.

- Bottazzi, V.; Boccelli, R.; Cattani, I.; Rebecchi, A. and Garbazza, C. (2000). Copper contamination of milk and cheese. Chemical, microbiological and enzymatic aspects. Latter 25(6): 68-75.

- Carl, M. (1991). Heavy metals and others trace elements. Monograph on residues and contaminants in milk and milk products. Chap. 6, pp. 113, international dairy federation, Belgium of lead, food additives. Contamin. 10: 325-335.

- Citek, J.; Rehout, V.; Kosvanec, K.; Hajic, F.; and Soch, M. (1995). Microelements in cow milk from different areas. [Czech]. SbornikJihoceska Univerzita Zemedelska Fakulta, Ceske Budejovice. Zootechnicka Rada 12(1): 69-76.

- Csapo, J. and Csapone, K.Z. (2002). Tejes tejtermekek a taplalkoza sab, Mesogazda, Kiado, Kaposvar, Hungar, p. 179-184. 
- Cussads, J. (1995). Lead, Cd, Hg contents in average Spanish market basket diet from goberia, Valancia, Alocia and Madrid Food Addit. Contam. Toxicol., 12(1): 107-118.

- Daganoc, D. (1999). Cadmium in food of animal origin from Slovenia: Concentrations in tissues of pigs and cattle during the period from 1993-1998. Zb. Vet. Fak. Univ. Ljubljana, 36(2): 231-242.

- Deeb, Azza M.M. (2010). Trace metals concentrations in cheese collected from Kafr El-Sheikh governorate, Egypt. Assiut Vet. Med. J., 56(127): 75-84.

- Dwivedi, S.K.; Warup, D. and Dey, S. (1997). Cadmium level in bovine milk from different industrial localities of India. Ind. J. Anim. Sci., 67(9): 758-759.

- Egyptian Organization for Standardization and Quality Control “E.O.S.Q.C." (1993). Maximum residue limits for heavy metal contaminants in food. Ministry of Industry, No. 2360, pp. 5, Cairo, Egypt.

- Egyptian Standard (1993). Maximum levels of heavy metals contaminants in food. Egyptian Organization for Standardization and Quality Control, E.S. no. 2360.

- El-Prince, Enas and A.A. Sharkawy (1999). Estimation of some heavy metals in bovine milk in Assiut governorate. Assiut Vet. Med. J. 41(81).

- El-Prince, Enas and Abd El-Mohsen, Manal (2001). Estimation of some metallic pollutants in dried weaning baby foods. Dept. of Food Hygiene; Fac. Vet. Med., Assiut University, Assiut. 
- FAO/WHO. (1993). Codex Classification of Foods and Animal Feeds in Codex Alimentarius, 2nd ed., Volume 2. Pesticide Residues, Section 2. Joint FAO/WHO Food Standards Programme. FAO, Rome.

- Farag, H.E.-S.M.; Neiazy, Zienab M. and Yassien, M.A.M. (2009). Levels of lead \& cadmium residues in tissues of bovine slaughtered in Port-Said governorate. Assiut Vet. Med., J. 55(123): 32-44.

- Gossel, T.A. and Bricker, J.D. (1990). Principles of clinical toxicology $2^{\text {nd }}$ Ed. Raven Press, New York, pp. 153-192.

- Goyer, R.A. (1993). Lead toxicity. Current concerns. Environ. Health Prespectives, 100: 177-187.

- Goyer, R.A. (1996). Toxic effect of metals. In: Casarett and Doull's toxicology. The Basic Science of Poisons. $5^{\text {th }}$ Ed. By Klassen, C.D., Amdur, M.O. and Doull, J. pp. 691-736.

- Gracey, J. and Collins, D. (1992). Meat Hygiene, $9^{\text {th }}$ ed., Elbs with Baillier Tindel. Chap. 10, pp. 20-5-221, London, UK.

- Hostynek, J.J.; Hinz, R.S.; Lorence, C.R.; Price, M. and Guy, R.H. (1993). Metals and skin. Critical Reviews in Toxicology, 3(2): 171235.

- Hummelen, T. (2007). The advantages of antibiotic testing. International Dairy Topics, 6(3): 23-25.

- IARC (1994). Cadmium, mercury, beryllium and the glass industry. IARC, Mongr. 58, Lyon, IARC.

- International Dairy Federation "IDF" (1979). Chemical residues in milk and milk products. Bulletin. I.D.F. Document, 133. 
- Jansen, M.M.T. (1996). Contaminants: In J. de Vries (Editor), Food Safety and toxicity-CRC press, London.

- Järup, I. (2003). Hazards of heavy metal contamination. Br. Med. Bull., 68: 167-82.

- Jeena Zagorska (2007). The evaluation of organic milk quality. Latvia University of Agriculture, Slovenia, Poland, Turkey, Hungary and Greece. Published in the editions approved by International External and Latvian Council of Science, SSS, Software package and MS EXCELL.

- Kahaniki, G.R.J. (2007). Chemical contaminants in milk and public health concerns: a review. International Journal of Dairy Science, 2(2):104-115.

- Maas, S.; Lucot, E.; Gimbert, F.; Crini, N.; Badot, P.M. (2011). Trace metals in raw cows' milk and assessment of transfer to comte cheese. Food Chemistry 129(1): 7-12.

- Miedzobrodzka, A.; Sikora, E. and Cieslik, E. (1995). The content of selected minerals and some heavy metals in food products from southern Poland. 2. Milk and dairy products. Zeszyty Naukowe Akademii Rolniczejim. Hugona Kollataja Wkrakowie, Technologia Zywnosci, 7: 89-94.

- Miyata, S.; Okuno, T.; Shimamura, Y. and Miyake, T. (1986). Agerelated changes of zinc absorption and excretion, in: Handbook on the Toxicology of Metals. Vol. 1, $2^{\text {nd }}$ Ed., Friberg, L., Nordberg, G.F. and Vouk, V.B. (eds). Elsevier, Amsterdam, p. 41. 
- Morcombe, P.; Petterson, D.; Ross, P. and Edwards, J. (1994). Soil and agronomic factors associated with cadmium accumulation in kidneys of grazing sheep. Australian Veterinary Journal, 71(12): 404406.

- Moreno Rojas, R.; Sanchez Segarra, P.J.; Garcia Martinez, M.; Gordillo Otero, M.J. and Amaro Lopez, M.A. (2000). Mineral composition of skimmed milk fruit added yoghurts-nutritional assessment. Mulchwissenschaft 55(9): 510-512.

- Nasr, I.N.; Sallam, A.A.A. and El-Khair, A.A.A. (2007). Monitoring of certain pesticide residues and some heavy metals in fresh cow's milk at Gharbia Governorate, Egypt. Journal of Applied Sciences, 7(20): 3038-3044.

- OSHA (2008). Occupational safety and Healthy Administration/200 constitution Ave., NW, Washington, DC 20210, V.S. Department of Labor, TT: 877-889-5627,www.osha.gov.

- Osweiler, G.D. (1996). Metals and minerals. In: Toxicology. William's and Wilkins, Philadelphia, Baltimore, Hong Kong, London; Munich, p. 204.

- Pavlovic, I.; Sikric, M.; Havranek, J.L.; Plavljanic, N. and Barjenovic, N. (2004). Lead and cadmium levels in rw cow's milk from an industrialized Croatian region determined by electrothermal atomic absorption spectrometry, Czech. J. Anim. Sci., 49(4): 164-168.

- Petrie, A. and Watson, P. (1999). Statistic for veterinary and animal science. $1^{\text {st }}$ Ed., pp. 90-99, the Blackwell Science Ltd., UK. 
- Robards, K. and Worsfold, P. (1991). Cadmium toxicology and analysis. Analyst. 116: 549-568.

- Sobeih, A.M.K. and Hegazy, H.M.R. (2011). Determination of some heavy metals in table hen's eggs. American Science Journal (International Journal). Brooklyn, NY 11212, USA.

- Tork, I.Y. (1996). Environmental heavy metal hazard in relation to animal health. Project Proposal, Fac. of Vet. med., Zagazig University, Egypt.

- Tsoumbaris, P. and Papadopoulou, T.H. (1994). Heavy metals in common food stuff: quantitative analysis. Bull. Environ. Contam. Toxicol., 53(1): 61-66.

- Ukic, L. (1998). The concentration of zinc and cadmium in alfalfa and cow's milk in the areas of Trepca and Obilic. Review of Research Work at the Faculty of Agriculture, Belgrade, 43(2): 83-94.

- Underwood, E.J. (1977). Trace Elements in Human and Animal Nutrition. $4^{\text {th }}$ Ed., Academic Press. Inc., London.

- Venalainen, E.; Niemi, A. and Hirvi, T. (1996). Heavy metals in tissues of hares in Finland 1980-82 and 1992-93. Bull. Environ. Contam. Toxicol., 56: 251-258.

- Wahter, M.E. (2007). Interactions between arsenic induced toxicity and nutrition in early life. J. Nutr., 137: 2798-2804.

- Watson, D. (1993). Chemical contaminants in: safety of chemicals in food. $1^{\text {st }}$ Ed. Ellis Horwood Limited,England.

- WHO (1995). Environmental health criteria series no. 165. Inogranic lead. World Health Organization, Geneva. 
در اسات على بعض المتبقيات و الملوثات المؤثرة على سلامة اللبن وبعض منتجاته إبراهيم محمد أمان ،عزة محمود كامل صبيح ، نهلة أحمد عبد الوهاب عبيد

يعتبر التلوث بالمعادن التقيلة من أخطر أنواع التلوث لما له من أنز سلبي على الجهاز العصبي والدم وتأثيره على مستوى الذكاء وبخاصة الأطفال ولما لهذه المعادن من أثز تراكمي في الجسم أجريت هذه الدراسة لتقدير بقايا المعادن النقيلة فى اللبن الخام وبعض منتجاته حيث تم تجميع 150 عينة (30 عينة من كل نوع) من اللبن الخام والجبن الطري والزبادي وبودرة الأيس كريم والأيس كريم من الدصانع الصغيرة بمحافظة كفرالثيخ خلال عامى 2010 ، 2011. تم تحليل هذه العينات لتقدير مستوى كل من الرصاص والكادميوم والزرنيخ والنحاس والزنك باستخدام جهاز الامنصاص الذرى وأوضحت النتائج وجود ارتفاع نسبة الرصاص والكادميوم عن الحد المسمح به فى العينات وغياب الزرنيخ من جميع العينات ، أما نسبة النحاس والزنك فى العينات موضع الدراسة كانت أعلى نسبيا من المسمح به. وقد تم مناقثة النتائج وخطورة نواجد هذه المعادن على الصحة العامة للإنسان وكذلك الاحتباطات اللازمة

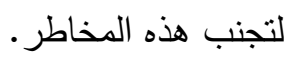

